\title{
Biogas Fermentation from Vegetable Waste and Horse Rumen Involving Effective Microorganism-4 (EM4)
}

\author{
Mimin Septiani $^{1, a}$, Irhamni Nuhardin ${ }^{2}$, Arief Muliawan ${ }^{3, b}$ \\ ${ }^{1,2}$ Department of Chemical Engineering, Sekolah Tinggi Teknologi Industri Bontang, Jalan Brigjend Katamso 40, Bontang, \\ Indonesia, 75313 \\ ${ }^{3}$ Department of Mechanical Engineering, Sekolah Tinggi Teknologi Industri Bontang, Jalan Brigjend Katamso 40, Bontang, \\ Indonesia, 75313 \\ amhimns@gmail.com \\ bariefstitek@gmail.com
}

\begin{abstract}
A vegetable waste is an organic matter that contains cellulose which potential to be processed into biogas with anaerobic fermentation process. The aims of this research are to find out how long time to produce biogas from vegetable waste and horse Rumen by using EM4, what does the effect of the addition of EM4 to the biogas yield and the content of the produced gas. Vegetables waste and Rumen rasio 1:1 (500g:500g). Water Content of 500g. Addition variable of EM4 in each digester are $0 \mathrm{ml}, 50 \mathrm{ml}, 100 \mathrm{ml}, 150 \mathrm{ml}$ dan $200 \mathrm{ml}$. Fermentation process takes time about 3 to 15 days. This result shows that the average time of fermentation lasts up to 11 days. The addition of $150 \mathrm{ml}$ EM4 generate the highest pressure, come to $322.801 \mathrm{~Pa}$, capable of producing the highest biogas yield of $0.2679 \%$ with $\mathrm{CO}_{2}$ content of $5.15 \%$.
\end{abstract}

Keywords-Biogas; Methane; EM4; Anaerobic

\section{Introduction}

Bioenergy from renewable sources began to be developed because of its environmentally friendly, nature, low production costs, and raw materials that are easily obtained. Organic waste is a material that makes biogas [1] through anaerobic fermentation process [2], this process produces a mixture of methane $\left(\mathrm{CH}_{4}\right)$, carbon dioxide $\left(\mathrm{CO}_{2}\right)$ and small amounts of nitrogen, ammonia, sulfur dioxide, hydrogen sulfide and hydrogen [3]. Biogas utilizes organic waste such as garbage, food scraps, animal waste and food industry waste [4]. Vegetable waste contains lots of organic material, therefore, it is easy to decompose, especially when the weather is warm [5], and if not managed, it will disturb the environment [6]. Vegetables that have been mechanically damaged or overripe can be quickly degraded by microorganisms [7]. Vegetable waste such as kale, mustard greens, and cabbage are waste that can produce gas [8].

Agricultural waste is generally rich in carbon (C) component but lacks of nitrogen component $(\mathrm{N})$. In contrast, livestock waste is generally rich in $\mathrm{N}$ but lacks of $\mathrm{C}$, therefore, it needs to be combined between agricultural waste and livestock waste [9]. Horse dung has a $\mathrm{C} / \mathrm{N}$ ratio of 25 which is higher than cow dung. A high $\mathrm{C} / \mathrm{N}$ ratio will determine the life and activity of microorganisms [10]. In addition, the fresh Rumen will be processed more easily than old and dried manure [11] with the help of EM4, it is expected to ferment quickly. EM4 can work efficiently without chemicals [12].

The processes that occur in the formation of biogas include hydrolysis, the stage of acid and acetic formation acidification, and the stage of methane formation (methanogenesis) [13]. Methanogenic and acidogenic bacteria are bacteria that play a role in the anaerobic digestion process. This bacterium is naturally present in wastes that contain organic matter [14].

The reaction stage of the cellulose material is as follows [16]:

$$
4 \mathrm{C}_{6} \mathrm{H}_{5} \mathrm{COOH}+24 \mathrm{H}_{2} \mathrm{O} \longrightarrow 12 \mathrm{CH}_{3} \mathrm{COOH}+4
$$

$\mathrm{HCOOH}+8 \mathrm{H}_{2}$

$$
\begin{aligned}
& 12 \mathrm{CH}_{3} \mathrm{COOH} \longrightarrow 12 \mathrm{CH}_{4}+12 \mathrm{CO}_{2} \\
& 4 \mathrm{COOH} \longrightarrow 4 \mathrm{CO}_{2}+\mathrm{H}_{2} \\
& 3 \mathrm{CO}_{2}+12 \mathrm{H}_{2} \longrightarrow 3 \mathrm{CH}_{4}+6 \mathrm{H}_{2} \mathrm{O}
\end{aligned}
$$

This fermentation process can be optimized by adding bioactivators EM4. This bioactivator consists of 90\% Lactobacillus $\mathrm{Sp}$ which produces lactic acid which can accelerate the process of breaking down organic 
matter such as cellulose [17]. In the research on biogas production from rice straw and green mustard waste, the addition of EM4 can increase biogas yield [18]. Besides the cyanide content in the waste can be reduced by using EM4 [19]. The concentration of the EM4 solution rises until it reaches its maximum value of the mole percentage of methane gas [20].

The purpose of this study is to examine the involvement of the Effective Microorganism-4 (EM4) solution in the biogas production process using vegetable waste and horse Rumen as a substrate.

\section{Research Methodology}

\section{A. Method}

Vegetable waste is obtained from a traditional market located at Makassar City. Horse feces were obtained from one of the slaughterhouses in the Bone district area. EM4 bioactivator used is $1 \%$. The main tool used is a biodigester reactor that has been designed using gallons with size of $600 \mathrm{ml}$. This study uses an anaerobic fermentation method to obtain data, namely the volume of gas produced and the time of fermentation.

\section{Fermentation Stage}

Vegetable waste, chopped with approximately size of $\pm 1 \mathrm{~cm}$. Horse Rumen is used as a bio starter. The ratio of vegetable waste and horse Rumen 1: 1 . Consists of 500 grams of vegetable waste and 500 grams of horse Rumen. Dilute with 500 grams of water. The addition of EM4 solution with an additional volume in each digester of $0 \mathrm{ml}, 50 \mathrm{ml}, 100 \mathrm{ml}, 150 \mathrm{ml}, 200 \mathrm{ml}$, then homogenized. Fermented with a time of 1 to 15 days.

2. Pressure Measurement Stage

The manometer hose is filled with a liquid that has been dyed, to get a vertical water size between the ends of the hose shaped "U". The ruler is attached to the side of the hose, with an initial start mark of $0 \mathrm{ml}$ at the end of the pipe filled with colored water. changes in fluid height were observed every afternoon at 17.00 WITA, readings were made for each type of digester tube.

$$
P^{\prime}=\rho \times g \times h
$$

Where as : $\mathrm{P}=$ Pressure

$$
\begin{aligned}
& \mathrm{g}=\text { Acceleration of Gravity }\left(9,81 \mathrm{~m} / \mathrm{s}^{2}\right) \\
& \rho=\text { Density of water }\left(997,13 \mathrm{~kg} / \mathrm{m}^{2}\right) \\
& \mathrm{h}=\text { Change in liquid height of the manometer }
\end{aligned}
$$

3. Gas Content Testing Stage

Testing of the resulting gas is carried out using the Ambient automotive gas tool

\section{B. Research Tool}

Research tool is shown in figure 1. It consist of a Digester, a Gas Collector and a Manometer.

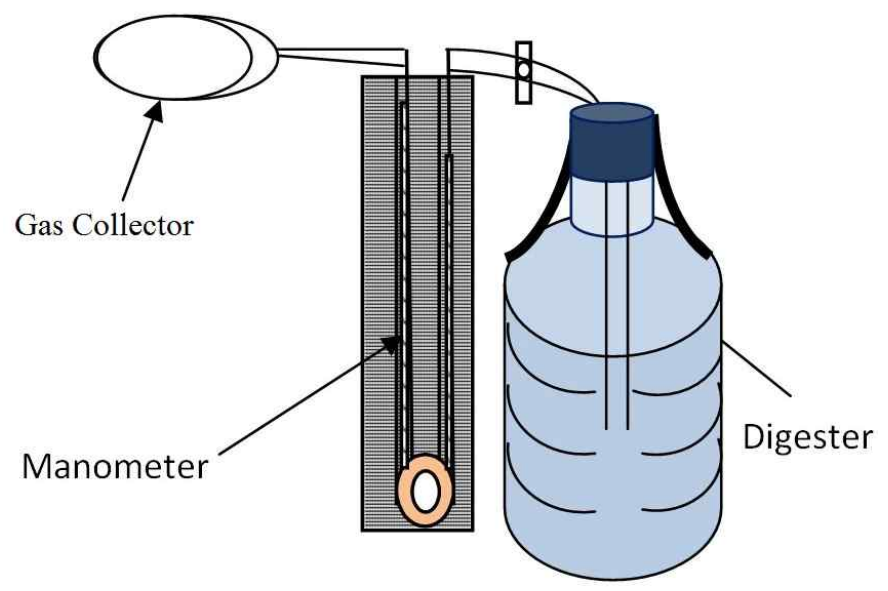

Figure 1. Research tool set models

\section{Results and Discussion}

\section{A. Effects of EM4 Addition on Fermentation Time}

The biogas fermentation time is presented in graphical form in Figure 2.

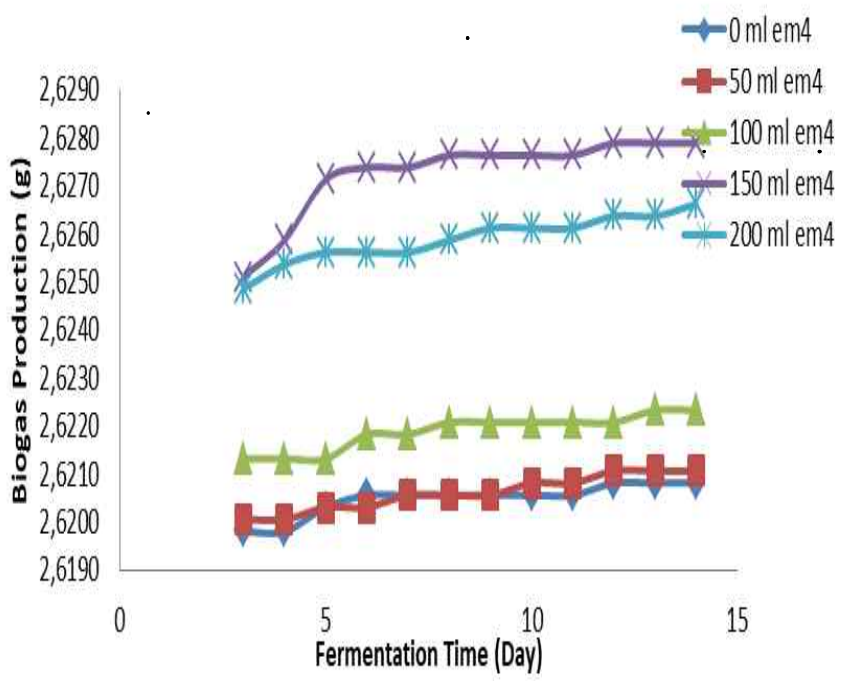

Figure 2. Correlation between fermentation time and biogas production

The graph shows that the composition of vegetable waste and horse Rumen without the addition EM4 began experiencing a production rate on day 3 of 2.6198 
grams and continued to increase until the 13th day of 2.6208 grams. In the composition with the addition of 50 ml EM4, biogas production began to occur on day 2 of 2.6201 grams and continued to increase until the 13th day of 2.6211 grams. In the composition with the addition of $100 \mathrm{ml}$ of EM4 gas production began on day 2 of 2.6213 grams and continued to increase until the 13th day of 2.6223 grams. On the addition of $150 \mathrm{ml}$ EM4, biogas production began on day 2 of 2.6251 grams, continuing to increase until the 11th day of. 2.6279 grams. For compositions with the addition of 200 ml EM4, biogas production began on day 2 of 2,6249 grams and continued to increase until day 15 of 2.6266 grams. This indicates that the process of decomposition organic substances that occur in vegetable waste with the addition of EM4 takes place faster than without the addition of EM4. EM4 is able to shorten the fermentation time of day 11. From figure 5 it can be seen that the largest increase in gas production occurs in the composition of vegetable waste and horse Rumen with the addition of $150 \mathrm{ml} \mathrm{EM} 4$ so that it is considered as the optimum volume of EM4 to a mixture of vegetable waste and horse Rumen.

\section{B. The Effect of EM4 Addition on Biogas Conversion}

The mixture of vegetable waste and horse Rumen without the addition of EM4 has the lowest biogas conversion when compared to the addition of EM4 as seen in figure 3.

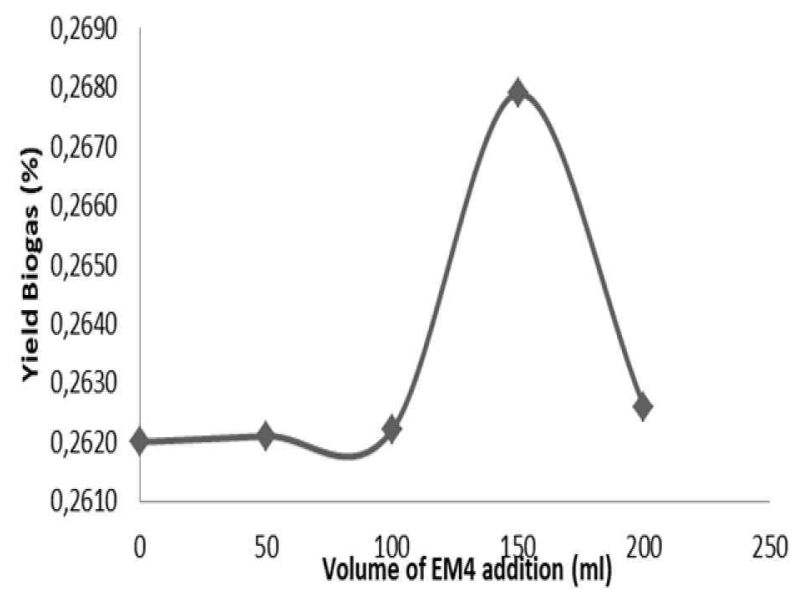

Figure 3. Correlation between the volume of EM4 addition to Biogas conversion

At $0 \mathrm{ml}$, EM4 yield of biogas produced by $0.2620 \%$, at the addition of $50 \mathrm{ml}$ EM4 results in biogas yield of $0,2621 \%$, the addition of $100 \mathrm{ml}$ EM4 yielded biogas yield of $0.2622 \%$, the addition of $150 \mathrm{ml}$ EM4 yielded a yield of $0.2679 \%$, and the addition of $200 \mathrm{ml}$
EM4 yielded biogas yield of $0.2626 \%$. The biggest biogas conversion is produced from the composition of vegetable waste and horse Rumen with the addition of $150 \mathrm{ml}$ EM4. The greater the volume of EM4 addition, the greater the biogas yield. The addition of EM4 can increase the production of gas produced.

At the addition of $200 \mathrm{ml} \mathrm{EM} 4$, there is a decrease in biogas production, this is because during the anaerobic process occurs the use of carbon and nitrogen sources by microbes, thereby reducing the value of $\mathrm{C} / \mathrm{N}$ [6]. The $\mathrm{C}$ / $\mathrm{N}$ ratio of organic matter largely determines microbial activity and biogas production. Adding too much EM4 can reduce the $\mathrm{C} / \mathrm{N}$ ratio, resulting in lower gas production [21].

\section{Gas Content Produced}

Gas testing is carried out using the Automotive Gas Ambient tool, which detects the total $\mathrm{CO}_{2}$ in the gas, so that the results obtained in the form of $\mathrm{CO}_{2}$ concentrations $(\%)$.

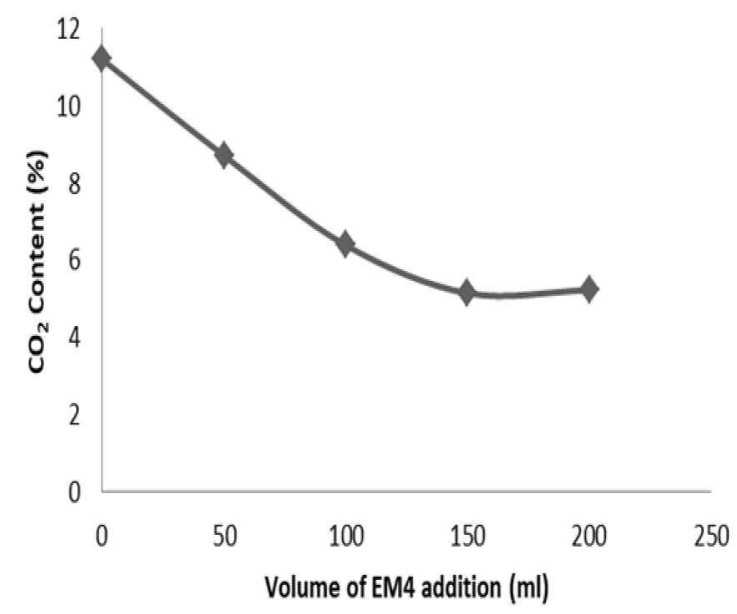

Figure 4. Correlation between the addition of EM4 to $\mathrm{CO} 2$ concentrations $(\%)$

Figure 4. shows the composition of vegetable waste and horse Rumen without the addition of EM4 having $\mathrm{CO}_{2}$ levels of $11.20 \%$. The addition of $50 \mathrm{ml}$ of EM4 produces $\mathrm{CO}_{2}$ of $8.71 \%$, an addition of $100 \mathrm{ml}$ of EM4 produces $\mathrm{CO}_{2}$ by $6.39 \%$, an addition of $150 \mathrm{ml}$ of EM4 results in a decrease in $\mathrm{CO}_{2}$ concentration to $5.15 \%$, in addition of $200 \mathrm{ml}$ of EM4 produces $5.23 \% \mathrm{CO}_{2}$. This data shows that the added EM4 volume has a significant effect on $\mathrm{CO}_{2}$ content. Biogas composition generally consists of $\mathrm{CO}_{2} 25-55 \%, \mathrm{CH}_{4} 45-70 \%, \mathrm{H}_{2} \mathrm{~S} \quad 10-30000$ $\mathrm{mg} / \mathrm{m}^{3}, \mathrm{~N}_{2}$ 0.01-5\%, $\mathrm{O}_{2}$ 0.01-2\%. Biogas produced in this study is considered safe because the $\mathrm{CO}_{2}$ levels contained in biogas are still within reasonable limits. 
With a lower $\mathrm{CO}_{2}$ content, the methane gas produced will be greater.
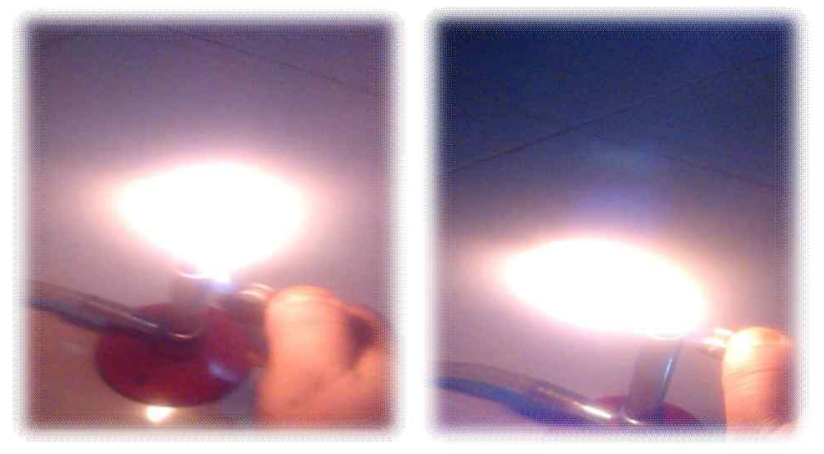

Figure 5. The flame test results at the optimum ratio

In accordance with the data presented in figures 3 and 4 , with the addition of $150 \mathrm{ml} \mathrm{EM} 4$, it is able to produce the most gas with the lowest $\mathrm{CO}_{2}$ concentration. And the results of a flame test that can last for 50 seconds.

\section{Conclusion}

Based on the results of research, data processing and analysis, it can be concluded that:

1. Fermentation lasts until the 11th day so that time is considered as the optimum time in the biogas fermentation process.

2. The optimum volume of EM4 solution in a mixture of vegetable waste and horse Rumen is $150 \mathrm{ml}$ with a biogas yield of $0.2679 \%$

3. Gas production from the optimum ratio contains the lowest $\mathrm{CO}_{2}$ gas of $5.15 \%$.

\section{Acknowledgement}

A big thank to the Universitas Muslim Indonesia and Sekolah Tinggi Teknologi Industri Bontang for making a positive contribution to this research.

\section{References}

[1] H. A. Romadhoni and P. Wesen, "Pembuatan Biogas dari Sampah Pasar," (Making Biogas from Market Waste), J. Ilm. Tek. Lingkung., vol. 6, no. 1, pp. 59-64, 2014.

[2] E. Yulistiawati, "Pengaruh Suhu dan C/N Rasio Terhadap Produksi Biogas Berbahan Baku Sampah Organik Sayuran," (Effect of Temperature and $\mathrm{C} / \mathrm{N}$ Ratio on Biogas Production Made from Raw Organic Vegetable Waste) Institut Pertanian Bogor, 2008.

[3] S. Fairus and L. Rahman, "Pemanfaatan Sampah Organik Secara Padu Menjadi Alternatif Energi: Biogas dan Precursor Briket," (Use of Organic Waste into Alternative Energy: Biogas and Briquette Precursors), No. 2006, 2011.
[4] P. Abdeshahian, J. Lim, W. Ho, H. Hashim, and C. . Lee, "Potential of biogas production from farm animal waste in Malaysia," Renew. Sustain. Energy Rev., vol. 60, pp. 714 723, 2016.

[5] J. Sutrisno, "Pembuatan Biogas Dari Bahan Sampah Sayuran (Kubis, Kangkung, dan Bayam)," (Making Biogas from Vegetable Waste Material (Cabbage, Kale, and Spinach), J. Tek. WAKTU, vol. 08, 2010.

[6] S. S. Erickson, E. Surya, and N. Herlina, "Pembuatan Pupuk Cair dan Biogas dari Campuran Limbah Sayuran," (Making Liquid and Biogas Fertilizers from Mixed Vegetable Waste) J. Tek. Kim., vol. 2, no. 3, pp. 40-43, 2013.

[7] E. A. Scano, C. Asquer, A. Pistis, L. Ortu, V. Demontis, and D. Cocco, "Biogas from anaerobic digestion of fruit and vegetable wastes: Experimental results on pilot-scale and preliminary performance evaluation of a full-scale power plant," Energy Convers. Manag., vol. 77, pp. 22-30, 2014.

[8] M. Natalia and P. Nugrahini, "Pengolahan Sampah Organik (Sayur-Sayuran) Pasar Tugu Menjadi Biogas dengan Menggunakan Starter Kotoran Sapi dan Pengaruh Penambahan Urea Secara Anaerobik Pada Reaktor Batch," (Processing of Organic Waste (Vegetables) Tugu Market into Biogas by Using a Cow Manure Starter and the Effect of Anaerobic Urea Addition on Batch Reactors), Tek. Kim. Fak. Tek. Univ. Lampung, pp. 1-6, 2014.

[9] T. Saputra, S. Triatmojo, and A. Pertiwiningrum, "Produksi Biogas dari Campuran Feses Sapi dan Ampas Tebu," (Biogas Production from A Mixture of Cow Feces and Bagasse), vol. 34, no. 2, pp. 114-122, 2010.

[10] A. S. Lestari, Z. Chaidir, and O. N. Tetra, "Produksi Biogas dari Limbah Cair Tahu dengan Menggunakan Starter Kotoran Kuda," (Biogas Production from Tofu Liquid Waste Using Horse Manure Starter), Kim. FMIPA Unand, no. 1, pp. 1-5, 2010.

[11] L. N. Aini, H. D. Mayasari, I. M. Riftanto, and M. R. Ariyanto, "Pembuatan Biodigester dengan Uji Coba Kotoran Sapi sebagai Bahan Baku," (Making Biodigester by Testing Cow Dung as Raw Material), Universitas Sebelas Maret, 2010.

[12] T. R. Ardiningtyas, "Pengaruh Penggunaan Effective Microorganism 4 ( EM4 ) dan Molase terhadap Kualitas Kompos dalam Pengomposan Sampah Organik," (Effect of Use of Effective Microorganism 4 (EM4) and Molasses on Compost Quality in Organic Waste Composting ), Lib. Unnes. 2013.

[13] Q. Zhang, J. Hu, and D. J. Lee, "Biogas from anaerobic digestion processes: Research updates," Renew. Energy, vol. 98, pp. 108-119, 2016.

[14] K. Hagos, J. Zong, D. Li, C. Liu, and X. Lu, "Anaerobic codigestion process for biogas production: Progress, challenges and perspectives," Renew. Sustain. Energy Rev., no. March, pp. 0-1, 2016.

[15] R. L. Mikkelsen, "Biuret in urea fertilizer," Fertil. Res., vol. 26, no. 1-3, pp. 311-318, 1990.

[16] P. J. Jørgensen, Biogas-Green Energy, 2nd Editio. Denmark: Faculty of Agricultural Sciences, Aarhus University, 2009.

[17] D. Irawan and E. Suwanto, "Pengaruh Em4 ( Effective Microorganisme ) terhadap Produksi Biogas Menggunakan Bahan Baku Kotoran," (Effect of Em4 (Effective Microorganism) on Biogas Production Using Dirt Raw Materials), Tek. Mesin, Univ. Muhammadiyah Metro, vol. 5, no. 1, pp. 44-49, 2016. 
[18] D. A. Herawati and A. A. Wibawa, "Pengaruh Pretreatment Jerami Padi pada Produksi Biogas dari Jerami Padi dan Sampah Sayur Sawi Hijau Secara Batch," (Effect of Rice Straw Pretreatment on Biogas Production from Rice Straw and Green Mustard Vegetable Trash by Batch), Vol. 4, No. 1, pp. 25-29, 2010.

[19] S. R. Juliastuti and G. A. Mertahardianti, "Pengaruh Enzim A-Amylase Pembuatan Biogas dari Limbah Padat Tapioka yang Melibatkan Effective Microorganism ( Em ) dalam Anaerobic Digester," (The Effect of The A-Amylase Enzyme Making Biogas from Tapioca Solid Waste Involving Effective Microorganisms (Em) In Anaerobic
Digester), Semin. Nas. Apl. Sains dan Teknol., vol. d, pp. 105-111, 2008.

[20] T. K. Dewi and C. K. Dewi, "Pembuatan Gas Bio dari Serbuk Gergaji, Kotoran Sapi, dan Larutan Em4," (Making Bio Gas from Sawdust, Cow Dung, and Em4 Solution), J. Tek. Kim., vol. 20, no. 1, pp. 1-9, 2014.

[21] K. W. Aji, "Pengaruh Penambahan EM4 ( Effective Microorganism -4 ) pada Pembuatan Biogas dari Eceng Gondok dan Rumen Sapi," (Effect of Addition of EM4 (Effective Microorganism -4) on the Production of Biogas from Water Hyacinth and Rumen Beef), Universitas Negeri Semarang, 2015. 